\title{
KINETICS OF SOIL UREASE AFFECTED BY UREASE INHIBITORS AT CONTRASTING MOISTURE REGIMES
}

\author{
Y.H. Juan ${ }^{1,2}$, L.J. Chen ${ }^{1 *}$, Z.J. Wu ${ }^{1}$ and R. Wang ${ }^{2}$ \\ ${ }^{1}$ Institute of Applied Ecology, Chinese Academy of Sciences, P. O. Box 417, Shenyang 110016, \\ People's Republic of China. ${ }^{2}$ Liaoning Academy of Agricultural Sciences, Shenyang 110161, \\ People's Republic of China. *Corresponding author: ljchenchina@hotmail.com
}

\begin{abstract}
With black soil (Pachic Udic Argiboroll) of Northeastern China as the test object, an incubation test was conducted to investigate the effects of urease inhibitors, hydroquinone (HQ), phenyl phosphorodiamidate (PPD) and N-(n-Butyl) thiophosphoric triamide (NBPT), on the kinetic characteristics of soil urease under normal moisture and waterlogged conditions, aimed to study the changes of catalytic potential of soil urease and the inhibition mechanisms. The results showed that test urease exhibited typical Michaelis-Menten kinetic behaviors, and all test inhibitors increased the $K_{m}$ and decreased the $V_{\max }$ of soil urease, behaving as mixed inhibitors to soil urease. Under both normal and waterlogged conditions, compared with HQ, PPD and NBPT made $K_{m}$ increase and $V_{\max }$ and $V_{\max } / K_{\mathrm{m}}$ decrease more greatly, and the duration of these effects was longer (ca. 30 days vs. 10 days). Under water-logging, PPD made more increment of $K_{m}$ and more decrement of $V_{\max }$ and $V_{\max } / K_{m}$ than NBPT, compared with that under normal soil moisture condition, suggesting that NBPT was more available under normal soil moisture condition, while PPD was promising under water-logging condition. To apply urease inhibitors and to control soil moisture condition could be a feasible way in increasing fertilizer $\mathrm{N}$ use efficiency affected by soil urease.
\end{abstract}

Keywords: kinetic parameters, mixed inhibition, moisture regime, soil urease

\section{INTRODUCTION}

Urea is the most frequently applied Nfertilizer in agriculture (Bremner, 1995), which accounts for $46 \%$ of the total world $\mathrm{N}$-fertilizer consumption (Watson, 2000). However, due to the rapid hydrolysis of its amide $\mathrm{N}$ by reaction with the enzyme urease, a quantitatively impressive loss of urea $\mathrm{N}$ as $\mathrm{NH}_{3}$ volatilization and $\mathrm{NO}_{3}{ }^{-}$ leaching could occur, and thus, a definite decrease of urea $\mathrm{N}$ use efficiency is observed (Cai et al., 2002; Sharpe and
Harper, 2002; Sommer et al., 2003; Blennerhassett et al., 2006; Parfitt et al., 2006).

To improve fertilizer $\mathrm{N}$ use efficiency, various attempts have been made to reduce the urea $\mathrm{N}$ loss (Vlek and Craswell, 1981; Byrnes and Freney, 1995; Blaise and Prasad, 1995), among which the use of urease and nitrification inhibitors in conjunction with urea fertilizer is an available option. 
Currently, a number of compounds, e.g., hydroquinone (HQ), phenyl posphorodiamidate (PPD), and N-(nbutyl) phosporothioic triamide (NBPT), etc., have been tested for their availability in inhibiting soil urease activity and in retarding urea hydrolysis (Wang et al., 1991a; Luo et al., 1994; Keerthisinghe and Freney, 1994). The effectiveness of these compounds applied to soils was affected by environmental factors, such as pH (Hendrickson and Douglass, 1993), temperature (Hendrickson and O'Connor, 1987), and moisture content (Sigunga et al., 2002; Clough et al., 2004). However, little information is available about the inhibitor effects on soil urease kinetics, which is of significance in understanding the types of inhibition mechanisms and the effectiveness of urease inhibitors.

\section{MATERIAL AND METHODS}

\section{Soil and inhibitors}

Surface black soil samples $(0-20 \mathrm{~cm})$ (Pachic Udic Argiboroll, US Soil Taxonomy) were collected from the Hailun Experimental Station of Ecology $\left(47^{\circ} 25^{\prime} \mathrm{N}, 126^{\circ} 46^{\prime} \mathrm{E}\right)$, Chinese Academy of Sciences, in Heilongjiang Province of Northeastern China. After removing plant roots and debris, soil samples were sieved $(<2 \mathrm{~mm})$, air-dried in shade, and stored for analysis.

The physicochemical properties determined as described by $\mathrm{Lu}$ (2000) were pH 6.45 (soil: water ratio, 1:2.5), organic C $29.20 \mathrm{~g} \mathrm{~kg}^{-1}$, total $\mathrm{N} 2.43 \mathrm{~g} \mathrm{~kg}^{-1}$, total $\mathrm{P} 0.82 \mathrm{~g} \mathrm{~kg}^{-1}$, total $\mathrm{S} 0.63 \mathrm{~g} \mathrm{~kg}^{-1}$, alkali-hydrolyzed $\mathrm{N} \quad 130.15 \mathrm{mg} \mathrm{kg} \mathrm{kg}^{-1}$, available $\mathrm{P} 105.24 \mathrm{mg} \mathrm{kg}^{-1}$, available $\mathrm{S}$ $22.9 \mathrm{mg} \mathrm{kg}^{-1}$, sand $13.85 \%$, clay $34.61 \%$, and silt $51.45 \%$.
Urease inhibitors HQ (99\%), PPD (97\%), and NBPT (99.5\%) were purchased from Sigma (USA), ACROS (Belgium), and Toronto Research Chemicals Inc. (Canada), respectively.

\section{Incubation test}

The air-dried soil samples were remoistened at $15 \%$ soil moisture content (SMC), and pre-incubated at $25^{\circ} \mathrm{C}$ for 21 $\mathrm{d}$ to restore microbial activities (Bandick and Dick, 1999; Zornoza et al., 2006). After pre-incubation, the samples were amended with HQ, PPD, and NBPT at rate of $50 \mathrm{mg} \mathrm{kg}^{-1}$ dry soil (about $1 \%$ on a urea weight basis), respectively. The samples under normal moisture condition were in plastic bags with the same amount (about $500 \mathrm{~g}$ inhibitor-added soil of 20\% SMC), while those under water-logging were in $150 \mathrm{~mL}$ stoppered Erlenmeyer flasks (about $5 \mathrm{~g}$ inhibitor-added soil of $15 \%$ SMC for each flask). Then, soil samples were incubated at $25^{\circ} \mathrm{C}$ under both normal moisture $(20 \%$ moisture content) and water-logging (with a $3-5 \mathrm{~cm}$ water layer) conditions.

During incubation, water loss (assessed by weight) was compensated daily by adding distilled water. Controls (without any urease inhibitor application) were incubated at the moisture conditions previously described. Three replicates were installed for each moisture regime.

\section{Urease (EC 3.5.1.5) activity assay}

At 1,10 , and $30 \mathrm{~d}$ during incubation, $5 \mathrm{~g}$ incubated soil was thoroughly mixed with $5 \mathrm{ml}$ urea solution with a series of concentrations $(5,10,15,25,35$, and 45 mmol L ${ }^{-1}$ ), and then incubated at $37 \pm 1^{\circ} \mathrm{C}$ for $5 \mathrm{~h}$. After incubation, the residual urea was extracted with $50 \mathrm{~mL} 2 \mathrm{~mol} \mathrm{~L}^{-1}$ $\mathrm{KCl}$ acetic phenyl mercury solution 
for $1 \mathrm{~h}$ on a rotary shaker, followed by filtration with quantitative filter paper $(\varphi 15 \mathrm{~cm})$ (Tabatabai, 1994), and determined by Continuum Flow Auto Analyzer 3 BRAN+LUEBBE, which involves the reaction of urea with diacetylmonoxime (DAM) in the presence of thiosemicarbazide (TSC), $\mathrm{H}_{3} \mathrm{PO}_{4}$, and $\mathrm{H}_{2} \mathrm{SO}_{4}$ under heating. The intensity of red color formed was measured at $527 \mathrm{~nm}$ wavelength by spectrophotometer. Soil urease activity was expressed as $\mathrm{mg}$ of hydrolyzed urea- $\mathrm{N} \mathrm{kg}^{-1}$ dry soil $5 \mathrm{~h}^{-1}$.

\section{Michaelis kinetic measurement}

parameters

The kinetic parameters $K_{m}$ and $V_{\max }$ were calculated by Lineweaver-Burk equation, the linear transformation of MichaelisMenten equation (Segel, 1975):

$$
\frac{1}{V}=\frac{K m}{V \max } \cdot \frac{1}{[S]}+\frac{1}{V \max }
$$

\section{Statistical analysis}

All data were calculated on the basis of oven-dried soil, and represented as means \pm standard deviation of $3 \times 3$ data. The effects of moisture regime, urease inhibitor, incubation time, and their interactions on the kinetic parameters of soil urease were analyzed by a two-way analysis of variance (ANOVA) with the General Linear Models (GLM) procedure of SPSS 11.5 for windows, and the differences among treatment means were performed by Duncan's multiple test at $\mathrm{p}<0.05$ (SPSS 2000).

\section{RESULTS AND DISCUSSION}

The two-way ANOVA results of kinetic parameters showed that moisture regime, urease inhibitor, incubation time, and their combinations mostly had significant effects on the $K_{m}, V_{\max }$, and $V_{\max } / K_{m}$ of soil urease (Table 1).

Compared with control, the amendment of test inhibitors made $K_{m}$ increase (Figure 1), possibly because of the formation of inhibitor-urease complex decreasing the affinity of urease for the substrate, or the partitioning effects between the bulk solution and the microsite of enzyme attachment (Goldstein, 1976). The increase of $K_{m}$ provided evidence that applying urease inhibitor in conjunction with urea could retard urea hydrolysis and increase the urea-N use efficiency (Wang et al., 1991b; Zhao and Zhou, 1991; Watson et al., 1994; Varel, 1997).

The effects of test inhibitors on $K_{m}$ differed with moisture regime, incubation time, and the kinds of inhibitors (Fig.1). Under water-logging, the effectiveness of test inhibitors in increasing $K_{m}$ followed the order of NBPT, PPD $>$ HQ on the 1st day of incubation, and PPD $>$ NBPT $>>$ HQ on the 10th day and by the end of the incubation. A similar trend was observed under normal moisture condition, except for the order of NBPT $>$ PPD $>>$ HQ on the 10th day and by the end of the incubation. The differences in the effectiveness of test inhibitors were likely ascribed to their structural and functional properties. Hydroquinone (HQ), as a derivate of phenol, was easily soluble and oxidable, resulting in its shorter lasting time and weaker effectiveness on soil urease, while to the contrary, PPD and NBPT, as the derivates of phosphorylamide (Schlegel et al., 1986; Byrnes and Freney, 1995), have similar structure to urea (Van Cleemput and Wang, 1991), making them have higher potential to compete with the specific substrate for urease active sites (McCarty et al., 1990; Chaiwanakupt et al., 1996). 
Table 1: Multiple factorial ANOVA of kinetic parameters of soil urease

\begin{tabular}{lcccccc}
\hline Factor & \multicolumn{2}{c}{$\boldsymbol{K}_{\boldsymbol{m}}$} & \multicolumn{2}{c}{$\boldsymbol{V}_{\max }$} & \multicolumn{2}{c}{$\boldsymbol{V}_{\max } / \mathbf{K}_{\mathrm{m}}$} \\
& $\boldsymbol{F}$ & $\boldsymbol{P}$ & $\boldsymbol{F}$ & $\boldsymbol{P}$ & $\boldsymbol{F}$ & $\boldsymbol{P}$ \\
\hline $\mathrm{A}^{\mathrm{a}}$ & 105.730 & $0.000^{* * * \mathrm{~b}}$ & 11.358 & $0.002 * *$ & 147.634 & $0.000^{* * *}$ \\
$\mathrm{~B}$ & 47.396 & $0.000^{* * *}$ & 310.294 & $0.000^{* * *}$ & 240.271 & $0.000^{* * *}$ \\
$\mathrm{C}$ & 149.978 & $0.000^{* * *}$ & 449.278 & $0.000^{* * *}$ & 413.699 & $0.000^{* * *}$ \\
$\mathrm{AB}$ & 16.428 & $0.000^{* * *}$ & 47.028 & $0.000^{* * *}$ & 50.949 & $0.000^{* * *}$ \\
$\mathrm{AC}$ & 1.011 & 0.374 & 79.321 & $0.000^{* * *}$ & 16.374 & $0.000^{* * *}$ \\
$\mathrm{BC}$ & 8.414 & $0.000^{* * *}$ & 57.008 & $0.000^{* * *}$ & 23.000 & $0.000 * * *$ \\
$\mathrm{ABC}$ & 5.467 & $0.002 * *$ & 34.091 & $0.000 * * *$ & 12.971 & $0.000^{* * *}$ \\
\hline
\end{tabular}

${ }^{a} \mathrm{~A}, \mathrm{~B}$ and $\mathrm{C}$ represent moisture regime, urease inhibitor, and incubation time, respectively.

$\mathrm{b} * *$ and $* * *$ represent $p<0.01$ and $<0.001$, respectively.

Compared with PPD, the better effectiveness of NBPT was due to its more functional groups (e.g., amino group, butyl, and thio group) (McCarty and Bremner, 1989) and a released sulfur group during its transformation (Blakeley and Zerner, 1984; Benini et al., 1996).

With incubation time, the $K_{m}$ decreased, but the duration restored the control level differed with the kinds of inhibitors. In water-logged treatment, the duration was about 10d under HQ and about 30d under PPD and NBPT; while in normal moisture treatment, it was longer under NBPT than under HQ and PPD (30 d vs. 10 d). The longer effectiveness of PPD and NBPT in water-logged and normal moisture conditions was probably due to the formation of more effective products, hydrolyzed product diamidophosphate (DAP) and oxon analog $\mathrm{N}$-(n-butyl) phosphoric triamide (BNPO), respectively (McCarty et al.,
1989; Creason et al., 1990; Manunza et al., 1999; Krajewska and Zaborska, 2007). Therefore, the duration and effectiveness of urease inhibitor on soil urease may be related to the rate and time of effective product formation, and the synergetic effects of inhibitor itself and the product (Douglass and Hendrickson, 1989).

Figure 2 showed the variation of $V_{\max }$ of urease. In principle, test inhibitors decreased the $V_{\max }$ of soil urease, due to the formation of inhibitor-enzyme complex decreasing the formation and dissociation of enzyme-substrate complex (Lai and Tabatabai, 1992). Under waterlogging, the effectiveness of test inhibitors in decreasing $V_{\max }$ was in the order of PPD $>$ NBPT $>$ HQ, while under normal moisture condition, the order was NBPT > PPD $>>\mathrm{HQ}$, due to their structural and functional characteristics mentioned above. 


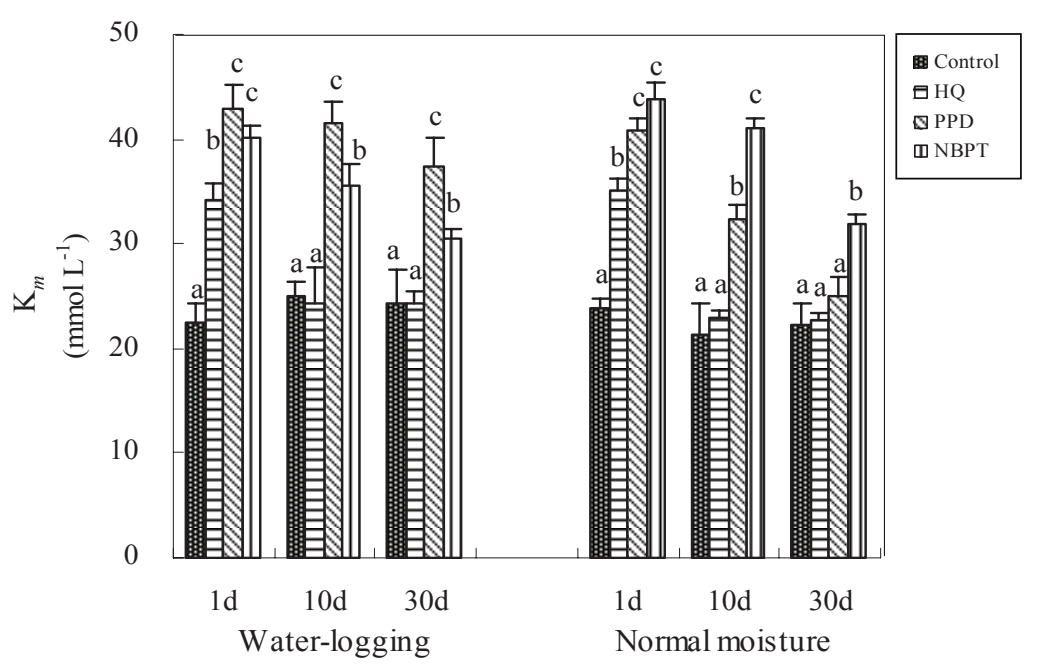

Figure 1: $K_{m}$ values of soil urease under effects of urease inhibitors. Values sharing the same small letter are not significantly different $(\mathrm{p}<0.05)$ according to the Duncan test

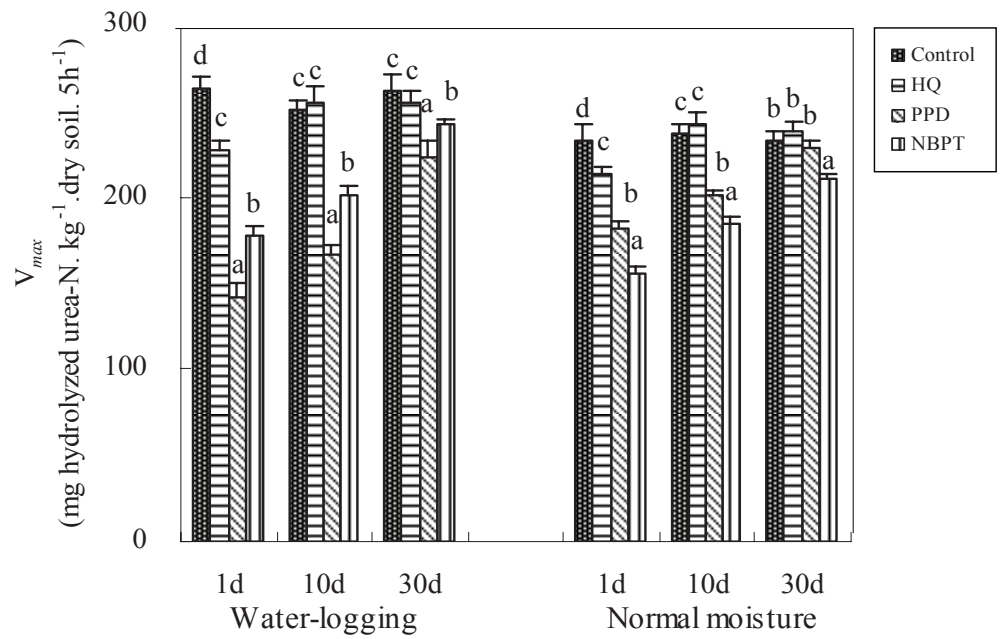

Figure 2: $V_{\max }$ values of soil urease under effects of urease inhibitors. Values sharing the same letter are not significantly different $(\mathrm{p}<0.05)$ according to the Duncan test 
With incubation time, $V_{\max }$ significantly increased (statistical results were not shown).

However, the time that $V_{\max }$ recovered to the control level differed. In general, the duration under PPD and NBPT was longer than that under $\mathrm{HQ}$ in both moisture conditions (ca. $30 \mathrm{~d}$ vs. $10 \mathrm{~d}$ ), which confirmed the previous studies that PPD and NBPT are more effective than HQ (Martens and Bremner, 1984; Luo et al., 1994).

$V_{\max } / K_{m}$ has been considered as an index of the catalytic capacity of enzyme through enzymatic reactions. Compared with control, $V_{\max } / K_{m}$ of soil urease significantly decreased with application of test inhibitors (data were not shown), indicating the decease of catalytic ability of test enzyme. Under soil moisture and incubation time conditions, the findings observed were similar to that of $V_{\max }$, suggesting that PPD and NBPT could greatly decrease the catalytic capability of urease under waterlogged and normal moisture conditions, respectively.

\section{CONCLUSIONS}

In general, the above results demonstrated that all test inhibitors were of mixed inhibition on soil urease, which was not in accordance with the previous study of PPD (Krajewska and Zaborska, 2007). Compared with HQ, PPD and NBPT made the kinetic parameters change more greatly, showing higher inhibitory effectiveness on soil urease. With incubation time, $K_{m}$ decreased, while $V_{\max }$ and $V_{\max } / K_{m}$ increased; however, the duration under PPD and NBPT was greatly longer than that under HQ (ca. 30 d vs. 10 d). Compared with normal moisture, water-logging increased $K_{m}$, but decreased $V_{\max }$ and $V_{\max } / K_{m}$ under PPD, while under NBPT, the changes of kinetic parameters were in adverse, indicating that PPD and NBPT are the most promising in water-logging and normal moisture, respectively.

Despite the fact that only a soil was studied, the results obtained are of significance and weight to make reliable conclusions of general interest that are presumably extendable to other soils and agricultural management practices. It is seen that to apply urease inhibitors and to control soil moisture could be a feasible way in increasing fertilizer $\mathrm{N}$ use efficiency, and a new standard for choosing a promising urease inhibitor may be potential by its effects on urease kinetics.

\section{ACKNOWLEDGEMENTS}

Financial supports from National Basic Research Program of China (973 Program) (2007CB109307) and Chinese Government Science and Technology Supporting Program (2006BAD10B01) are gratefully acknowledged. We thank Professor L. K. Zhou for his critical review of our manuscript, and the staffs of Department Soil and Plant Nutrition, Institute of Applied Ecology under Chinese Academy of Sciences for their academic and technical assistance.

\section{REFERENCES}

Bandick, A. K., Dick, R. P. 1999. Field management effects on soil enzyme activities. Soil Biol. Biochem. 31, 1471-1479.

Benini, S., Gessa, C., Ciuril, S. 1996. Bacillus pasteurii urease: A heteropolymeric enzyme with a binuclear nickel active site. Soil Biol. Biochem. 28(6), 819-821. 
Blaise, D., Prasad, R. 1995. Effect of blending urea with pyrite or coating urea with polymer on ammonia volatilization from surface applied prilled urea. Biol. Fertil. Soils 20, 83-85.

Blakeley, R., Zerner, B. 1984. Jack bean urease: the first nickel enzyme. J. Mol. Catal. 23(2), 263292.

Blennerhassett, J. D., Quin, B. F., Zaman, M., Ramakrishnan, C. 2006. The potential for increasing nitrogen responses using Agrotain treated urea. Proceed NZ Grassland Assoc. 68, 297-301.

Bremner, J. M. 1995. Recent research on problems in the use of urea as a nitrogen fertilizer. Fertil. Res. 42, 321-329.

Byrnes, B. H., Freney, J. R. 1995. Recent developments on the use of urease inhibitors in the tropics. Fertil. Res. 42, 251-259.

Cai, G. X., Chen, D. L., Ding, H., Pacholski, A., Fan, X. H., Zhu, Z. L. 2002. Nitrogen losses from fertilizers applied to maize, wheat and rice in the North China Plain. Nutr. Cycling Agroecosyst. 63, 187-195.

Chaiwanakupt, P., Freney, J. R., Keerthisinghe, D. G., Phongpan, S., Blakeley, R.. L. 1996. Use of urease, algal inhibitors, and nitrification inhibitors to reduce nitrogen loss and increase the grain yield of flooded rice (Oryza sativa L.). Biol. Fertil. Soils. 22(1-2), 89-95.

Clough, T. J., Kelliher, F. M., Sherlock, R. R., Ford, C. D. 2004. Lime and soil moisture effects on nitrous oxide emissions from a urine patch. Soil Sci. Soc. Am. J. 68, 1600-1609.

Creason, G. L., Schmidt, M. R., Douglass, E. A., Hendrickson, L. L. 1990. Urease inhibitory activity associated with $\mathrm{N}$-(n-butyl) thiophosphoric triamide is due to formation of its oxonanalog. Soil Biol. Biochem. 22(2), 209-211.
Douglass, E. A., Hendrickson, L. L. 1989. Urease inhibition by $\mathrm{N}$-(n-butyl) thiophosphoric triamide and its oxon analog in diverse soils. Agronomy Abstracts 214.

Goldstein, L. 1976. Kinetic behaviour of immobilized enzyme systems. pp: 397-443. In K. Mosbach (eds.) Methods in enzymology. Vol. 44. Academic Press, London.

Hendrickson, L. L., Douglass, E. A. 1993. Metabolism of N-(n-butyl) phosporothioic triamide (NBPT) in soils. Soil Biol. Biochem. 25(11), 1613-1618.

Hendrickson, L. L., O'Connor, M. J. 1987. Urease inhibition by decomposition products of phenylphosphorodiamidate. Soil Biol. Biochem. 19(5), 595-597.

Keerthisinghe, D. G.., Freney, J. R. 1994. Inhibition of urease activity in flooded soils: Effect of thiophosphorictriamides and phosphorictriamides. Soil Biol. Biochem. 26, 1527-1533.

Krajewska, B., Zaborska, W. 2007. Jack bean urease: The effect of active-site binding inhibitors on the reactivity of enzyme thiol groups. Bioorganic Chemistry. 35(5), 355-365.

Lai, C. M., Tabatabai, M. A. 1992. Kinetic parameters of immobilized urease. Soil Biol. Biochem. 24(3), 225-228.

Lu, R. K (ed). 2000. Methods of soil and agrochemistry analysis. Chinese Agricultural Science and Technology Press, Beijing (in Chinese).

Luo, Q. X., Freney, J. R., Keerthisighe, D. G.., Peoples, M. B. 1994. Inhibition of urease activity in flooded soils by phenylphosphorodiamide and N-(n-butyl) thiophosphorictriamide. Soil Biol. Biochem. 26(8), 1059-1065. 
Manunza, B., Deiana, S., Pintore, M., Gessa, C. 1999. The binding mechanism of urea, hydroxamic acid and N-(n-butyl)-phosphoric triamide to the urease active site. A comparative molecular dynamic study. Soil Biol. Biochem. 31, 789-796.

Martens, D. A., Bremner, J. M. 1984. Effectiveness of phosphoroamides for retarding of urea hydrolysis in soils. Soil Sci. Soc. Am. J. 48, 302-305.

McCarty, G. W., Bremner, J. M. 1989. Formation of phosphoryl triamide by decomposition of thiophosphoryl triamide in soil. Biol. Fertil. Soils. 8, 290-292.

McCarty, G. W., Bremner, J. M., Chai, H. S. 1989. Effect of $\mathrm{N}$-(n-butyl) thiophosphoric triamide on hydrolysis of urea by plant, microbial and soil ureases. Biol. Fertil. Soils. 8,123-127.

McCarty, G. W., Bremner, J. M., Lee, J. S. 1990. Inhibition of plant and microbial urease by phosphoroamides. Plant and Soil. 127, 269-283.

Parfitt, R. L., Schipper, L. A., Baisden, W. T, Elliott, A. H. 2006. Nitrogen inputs and out puts for New Zealand in 2001 at national and regional scales. Biogeochemistry. 80, 71-88.

Schlegel, A. J., Nelson, D. W., Sommers, L. E. 1986. Field evaluation of urease inhibitors for corn production. Agronomy Journal. 78, 1007 1012.

Segel, I. H. 1975. Enzyme Kinetics. Wiley, New York.

Sharpe, R. R., Harper, L. A. 2002. Nitrous oxide and ammonia fluxes in soybean field irrigated with swine effluent. J. Environ. Qual. 31, 524-532.

Sigunga, D. O., Janssen, B. H., Oenema, O. 2002. Ammonia volatilization from Vertisols. Eur. J. Soil Sci. 53,195-202.
Sommer, S. G., Genermont, S., Cellier, P., Hutchings, N. J., Olsen, J. E., Morvan, T. 2003. Processes controlling ammonia emission from livestock slurry in the field. Eur. J. Agron. 19, 465-486.

SPSS 2000. SPSS 10.0 for windows. SPSS, Chicago, IL

Tabatabai, M. A. 1994. Soil enzymes. In: R. W. Weaver, J. R. Angle, P. S. Bottomley (eds). Methods of soil analysis. Part 2: microbiological and biochemical properties. Soil Science Society of America, Madison, WI, pp: 775-833.

Van Cleemput, O., Wang, Z. P. 1991. Urea transformation and urease inhibitors. Trends in Soil 1, 45-52.

Varel, V. H. 1997. Use of urease inhibitor to control nitrogen loss from livestock waste. Bioresour. Technol. 62, 11-17.

Vlek, P. L. G., Craswell, E. T. 1981. Ammonia volatilization from flooded soils. Fertil. Res. 2, 227-245.

Wang, Z. P., Li, L. T., Van Cleemput, O., Baert, L. 1991a. Effect of urease inhibitors on denitrification in soil. Soil Use and Management. 7(4), 230-233.

Wang, Z. P., Van Cleemput, O., Demeyer, P. 1991b. Effect of urease inhibitors on urease hydrolysis and ammonia volatilization. Biol. Fertil. Soils. 11, 43-47.

Watson, C. J. 2000. Urease activity and inhibition-principles and practice. Proceeding of the International Fertilizer Society.

Watson, C. J., Miller, H., Poland, P., Kilpatrick, D. J., Allen, M. D. B., Garrett, M. K., Christianson, B. C. 1994. Soil properties and the ability of the urease inhibitor N-(n-butyl) thiophosphotic triamide (NBPT) to reduce ammonia volatilization from surface-applied urea. Soil Biol. Biochem. 26(9), 1165-1171. 
Yavitt, J. B., Wright, S. J., Wieder, R. K. 2004. Seasonal drought and dry-season irrigation influence leaf-litter nutrients and soil enzymes in a moist, lowland forest in Panama. Austral Ecology. 29, 177-188.

Zhao, X. Y., Zhou, L. K. 1991. Effect of urease inhibitor hydro quinone on soil enzyme activity. Soil Biol. Biochem. 23(11), 1089-1091.
Zornoza, R., Guerrero, C., Mataix-Solera, J. M., Arcenegui, V., Garcia-Orenes, F., MataixBeneyto, J. 2006. Assessing air-drying and rewetting pre-treatment effect on some soil senzyme activities under Mediterranean conditions. Soil Biol. Biochem. 38, 2125-2135. 